\title{
URINARY INCONTINENCE AND EXERCISE: KINESIOLOGICAL DESCRIPTION OF AN INTERVENTION PROPOSAL
}

\author{
INCONTINÊNCIA URINÁRIA E EXERCICIO:DESCRIÇÃO CINESIOLÓGICA DE UMA PROPOSTA DE INTERVENÇÃO
}

INCONTINENCIA URINARIA Y EJERCICIO:DESCRIPCIÓN KINESIOLOOGICA DE UNA PROPUESTA DEINTERVENCIÓN

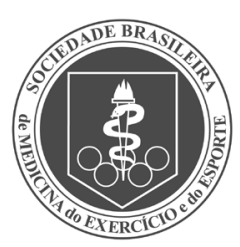

Original Article

ARTIGO ORIGINAL

Artículo Original
Aletha Silva Caetano $0^{1,2}$

(Physical Education Professional)

Frank Shiguemitsu Suzuki 1,3

(Physical Education Professional)

Maria Helena Baena de Moraes

Lopes $^{2}$ (Nurse)

1. Universidade Nove de Julho, São Paulo, SP, Brazil.

2. Universidade Estadual de Campinas, Campinas, SP, Brazil.

3. Universidade São Judas Tadeu,

São Paulo, SP, Brazil.

\section{Correspondence:}

Aletha Silva Caetano.

Rua Barão de Tefé, 37, apto. 124,

Água Branca, São Paulo, SP,

Brazil. 05003-040.

alethacaetano@uninove.br

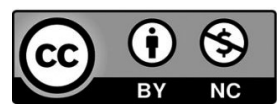

\begin{abstract}
Introduction: Research shows that symptoms of urinary incontinence are common among women who engage in physical activity. Objective: To conduct a kinesiological analysis of specific exercises for the pelvic floor muscles (PFM), proposing correspondences of these postures through resistance exercises. Methods: This research project is of a descriptive nature with level of evidence V. Videos and photos were taken to obtain an image for the collection of data based on the accomplishment of the specific postures. Results: The kinesiological study revealed that the muscles involved in the postures of exercises targeting the prevention of urinary incontinence beyond those specific to the pelvic floor were: trunk flexors; spinal erector; adductors and hip extensors. The resistance exercises corresponding to these positions in bodybuilding apparatus were the machine hack squat; sitting adductor exercises; sitting abductor exercises; the smith machine squat and the free squat or machine squat. Conclusion: This study showed that it is possible to construct correspondence between exercises for the pelvic floor muscles and resistance exercises with bodybuilding equipment and free weights. A new strategy is suggested for the physical education professional, based on resistance exercises: taking a coadjuvant approach to the treatment and prevention of urinary incontinence during physical and sports exercises. Level of evidence V, Case series.
\end{abstract}

Keyword: Exercise; Urinary incontinence; Urinary incontinence, stress; Pelvic floor.

\section{RESUMO}

Introdução: Pesquisas mostram que os sintomas da incontinência urinária são comuns entre mulheres que praticam atividade física. Objetivo: Realizar análise cinesiológica de exercícios específicos para os músculos do assoalho pélvico, propondo correspondências destas posturas por meio de exercícios resistidos. Métodos: Esta pesquisa é de natureza descritiva com nível de evidência V. Foram realizadas filmagens e fotos, para obtenção de imagem para a coleta de dados, a partir da realização das posturas específicas. Resultados: O estudo cinesiológico revelou que os músculos envolvidos nas posturas de exercícios para a prevenção da incontinência urinária além daqueles específicos do assoalho pélvico foram: os flexores de tronco; os eretores da espinha; os adutores e os extensores de quadril. Os exercícios físicos resistidos correspondentes para estas posturas em aparelhos de musculação foram o hack machine, a cadeira adutora, a cadeira abdutora, o agachamento smith machine e o agachamento livre ou na máquina. Conclusão: É possível a construção de correspondência entre os exercícios para os músculos do assoalho pélvico e exercícios resistidos com equipamentos de musculação e pesos livres. Sugere-se nova estratégia para o profissional de educação física, a partir de exercícios resistidos, a saber: realizar abordagem coadjuvante para o tratamento e a prevenção da incontinência urinária durante a prática de exercícios físicos e esportivos. Nível de evidência V, Série de casos.

Descritores: Exercício; Incontinência urinária; Incontinência urinária por estresse; Diafragma da pelve.

\section{RESUMEN}

Introducción: Las investigaciones muestran que los sintomas de la incontinencia urinaria son comunes entre las mujeres que realizan actividad física. Objetivo: Realizar análisis kinesiológico de ejercicios específicos para los músculos del suelo pélvico, proponiendo correspondencias de estas posturas por medio de ejercicios resistidos. Métodos: Esta investigación es de naturaleza descriptiva con nivel de evidencia V. Fueron realizadas filmaciones y fotos, para obtención de imagen para la recolección de datos a partir de la realización de las posturas específicas. Resultados: El estudio kinesiológico reveló que los músculos involucrados en las posturas de ejercicios para la prevención de la incontinencia urinaria, además de aquellos específicos del suelo pélvico fueron: Ios flexores de tronco; los erectores de la espina dorsal; los aductores y los extensores de cadera. Los ejercicios físicos resistidos correspondientes para estas posturas en aparatos de musculación fueron: hack machine; silla aductora; silla abductora; sentadilla smith machine y sentadilla libre o en la máquina. Conclusión: Es posible la construcción de correspondencia entrelos ejercicios para los músculos del suelo pélvico yejercicios resistidos con equipos de musculación y pesos libres. Se sugiere nueva estrategia para el profesional de educación física, a partir de ejercicios resistidos, a saber: realizar un enfoque coadyuvante para el tratamiento y la prevención de la incontinencia urinaria durante la práctica de ejercicios físicos y deportivos. Nivel de evidencia V, Serie de casos.

Descriptores: Ejercicio; Incontinencia urinaria; Incontinencia urinaria de esfuerzo; Diafragma pélvico. 


\section{INTRODUCTION}

Urinary incontinence (UI) is defined by the International Continence Society (ICS) as a "complaint of any involuntary loss of urine"1. The most common type of $\mathrm{UI}$ among women is stress urinary incontinence (SUI), defined as a complaint of involuntary loss of urine in the effort (such as sneezing or coughing) or exercise (eg, sports activities), and is responsible for almost half of the cases and more commonly affects young women between the ages of 25 and $49^{2}$.

Among women practicing physical and sporting exercise, the most common type identified is SUI, and their prevalence can vary from $20 \%$ to $85 \%$ considering the definition used, age range, parity, type, frequency and intensity of activity ${ }^{3-5}$. Although the literature is not conclusive in this respect, studies show that exercises that require a lot of physical effort and demand high impact may cause an excessive increase in intra-abdominal pressure. This increase can overwhelm the pelvic organs, pushing them down, causing damage to the muscles responsible for the support of these organs ${ }^{6-18}$.

The first studies that describe the relationship between physical exercise and symptoms of UI have appeared since the 1980s, with physiotherapist Kari $\mathrm{Bo}^{6-7}$ and the gynecologist Ingrid E. Nygaard ${ }^{8-10}$. Subsequently new studies were published by the same authors, as well as other researchers, with different methodological designs ${ }^{11-15}$.

Recent research confirms the results of previous investigations regarding the significant prevalence of UI among young athletes of different high impact modalities such as trampoline, jump, step, running, volleyball and soccer ${ }^{16-18}$.

A review study by Caetano and colleagues ${ }^{19}$ showed the importance of informing physical activity practitioners, whether athletes or not, of the relationship between physical exertion, mainly high impact, and SUI, ways of preventing UI, besides recommend that the exercises be performed in order to prevent $\mathrm{Ul}$; in order to reduce abandonment and seek to ensure that women are not deprived of the benefits inherent in the practice of physical activities in a general way ${ }^{20-21}$.

Another review study ${ }^{22}$ by author Caetano in $2012^{22}$ did not find articles intended for Physical Education professionals that aggregated information and allowed a deeper understanding of the relationship between SUI and physical exercises, such as description of anatomical, kinesiological and biomechanical parameters. This does not allow this professional to base the prescription of physical exercises more adequate, safe and efficient for women with SUI.

Thus, the objectives of the present study were: (1) to perform the kinesiological description of specific exercises for the prevention of SUI; and (2) to establish the correspondence of these specific postures (for the prevention of SUI) with resisted physical exercises.

\section{METHODS}

This research is descriptive in nature. The lead researcher (model) performed the specific poses that were filmed and photographed by a research team member.

In the description of the anatomical parameters we used the book Clinical Kinesiology and Anatomy ${ }^{23}$. To describe the correspondences between the specific postures of the exercises for the prevention of UI (Figure 1) with the resistance exercises proposed, we used the books Kinesiology of the Musculoskeletal Apparatus ${ }^{24}$.

For the beginning of image collection, the model received markings (reflective spherical adhesive marks $19 \mathrm{~mm}$ in diameter) at specific anatomical points (Figure 2)

Filming was performed using a Panassonic digital video camera with a capacity of $\geq 30 \mathrm{~Hz}$, 60 frames per second, supported on tripods, at a certain distance from the model placed at a height that allowed the

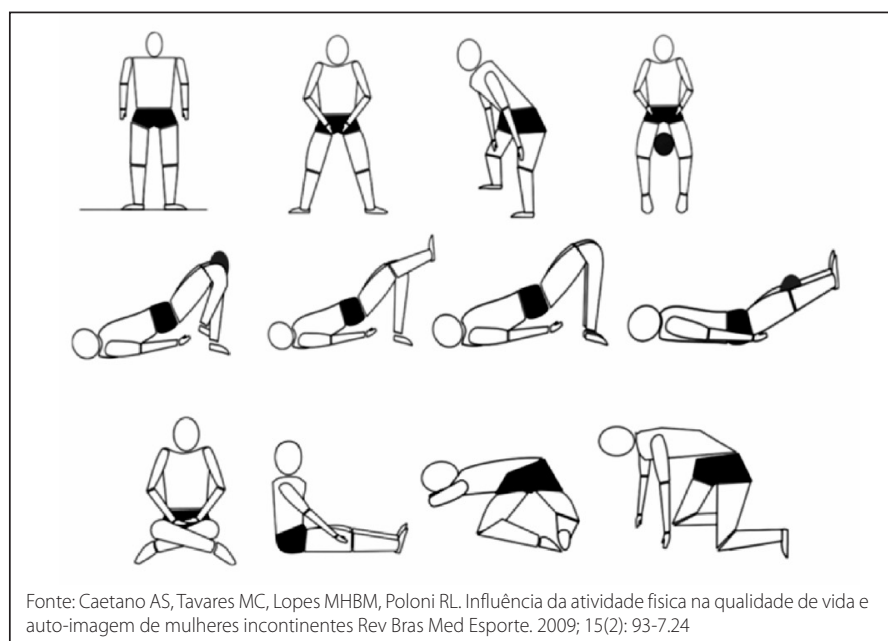

Figura 1. Posturas específicas para a realização de exercícios para o assoalho pélvico.

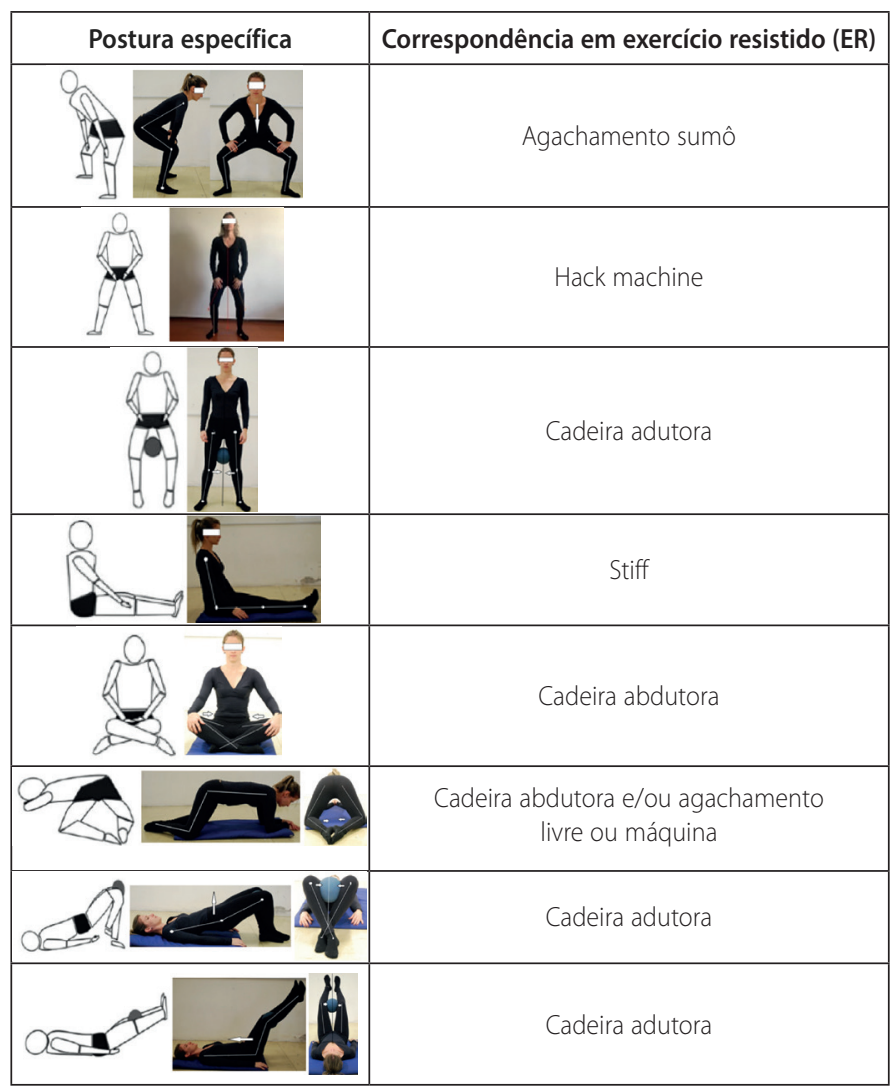

Figura 2. Posturas específicas para a realização dos exercícios para o assoalho pélvico e sua correspondência com exercícios resistidos.

model to be centralized in the focus, forming between the cameras and the model an angle of $90^{\circ}$ (Figure 2). The camera's shooting range was adjusted to capture the best angle for motion analysis.

The calculations of all kinematic variables were made using the program Kinovea Video Editor, a video treatment application dedicated to editors of sports programs, which has special features such as stopwatch, zoom and others. The three-dimensional coordinates of the anatomical points marked in the model, which are the output variables of the program, were used as inputs.

\section{RESULTS}

The parameter presented in this work refers to the kinesiological parameters of figures previously published and are presented and referenced in Figure $1^{19}$. These figures served as a basis for the production of the photographic images presented later. 
After the kinesiological evaluation of the proposed postures (Figure 1) we found similarities in different muscle groups:

1. Flexors of trunk (rectum of the abdomen, oblique internal and external abdomen).

2. Erectors of the spine (iliocostal, very long and spinal).

3. Adductors (adductor magno, short and long, sartorius and gracilis).

4. Hip extensors (gluteus maximus, semitendineum, semimembranaceus and femoral biceps).

After identifying the muscle groups described from this kinesiological study, we searched for each posture a corresponding identification of the same muscle work through exercises resisted by the bodybuilding method. Figure 2 presents this correspondence taking into account some of the figures presented for each posture, individually.

\section{DISCUSSION}

In view of our experience as physical educators in gymnasiums and gymnastics in general, as well as in sports squares and sports training, it is possible to affirm that systematized guidelines for the practice of specific physical exercises for the prevention of SUI by coaches, instructors and teachers in their respective places of professional activity. In this sense, most of the athletes and physical exercise practitioners are unaware of the existence of potential gynecological problems that can occur with this practice. One study ${ }^{25}$ identified in a survey of athletes that among those with UI symptoms, most had never discussed the problem with their coach, revealing that this is an uncomfortable and embarrassing situation for sports.

The literature suggests that specific exercises to prevent UI among active women out of the competitive range can benefit them, behaving as a potential protective factor when smoothing the symptoms of urinary loss $5,12,19$. However, this subject of study is recent and little explored among professionals of physical education. According to a study by Thowsend 26 and colleagues, moderate-intensity physical exercises may be associated with a reduction in complaints of urine loss during and out of exercise. In these studies it was found that a high frequency of physical exercise (eg walking) is positively correlated with the decrease in SUI in a sample of women between 37 and 54 in the first study and 54 to 79 years of age in the second, regardless of the index of body mass.

There are two hypotheses that may relate to the onset of UI or exacerbation of symptoms. According to Kari $\mathrm{BO}^{27}$, an unconscious contraction of the pelvic floor muscles (MAP) may occur in response to any increase in intra-abdominal pressure that can be caused by high-impact physical exercise, generating forces of reaction to the ground. In this sense, an increase in the MAP tonus among continents women would be expected. Otherwise, according to the same author, physical exercises with high impact could contribute to the weakening of the MAP, mainly due to the lack of training and preparation of these muscles to receive these demands. This hypothesis would justify the appearance of involuntary loss of urine among nulliparous athletes (who never gave birth) or with no apparent predisposition to the development of the disease.

The results of this study showed that the muscles that are activated, when performing the specific postures contained in figure 1 are the flexor muscles of the trunk; spine erectors, and hip extensors and adductors. In this sense, investigations have shown that the contraction of the adductor muscles of the hip and gluteus leads to a synergistic and unconscious contraction of the MAP muscles as well as the striated portion of the urethral wall, leading to an increase in the pressure of this region in rest and, possibly to an increase in the muscle tone of the MAP28,29.
Some recent studies present discussions regarding the training of the transverse abdominal muscles. According to the authors, the activation would occur from a synergistic muscle activity of the MAP and the transverse abdominal muscles during physical activities that would use the trunk ${ }^{29}$. In order to confirm or refute this theory, a theoretical study was carried out between 1997 and 2007 using different databases ${ }^{19}$. The results identified in the above study showed that while a contraction of the transverse abdominal muscles normally occur with MAP contraction, evidence suggests that MAP co-contraction from contraction of the transverse abdominis may be lost or impaired in women with UI. In this sense the professional should be aware during his intervention if the approach is being performed with women with or without UI.

As was initially emphasized, in no study was a systematized intervention proposal as a preventive strategy for SUI during sports training and physical activities. The research proposed in this study meets this shortcoming in the literature, establishing a comparative relationship between the specific postures for MAP exercises and resistance exercises, which correspond to the same muscular activation that would allow a synergistic contraction of the MAP.

Recently, an investigation has been identified in the literature that proposed to work out resistance exercises for women with $\mathrm{UI}^{30}$. The researchers used different physical exercises that allowed the activation of muscles that would synergistically activate MAP. According to the authors of this study, after the practice of the resisted exercises in a period of three months, a significant improvement in the complaints of urine loss among the volunteers was observed from the parameters evaluated in the voiding diary: episode volume of loss and protector changes ( $p<0.001$ ). The results also showed adherence to the program of $85 \%$ of participants and no worsening of symptoms was identified.

Although specific pelvic floor exercises have been shown to be effective in preventing and improving UI symptoms among women, particularly considering those who practice sports and who have UI symptoms, we have not identified any surveys they have used as part of the training specific exercises to prevent urine leakage before and / or during this practice. This fact suggests a gap in the physical preparation and specific training of this population, since SUI has been reported as a frequent problem among athletes and women who practice regular physical exercises ${ }^{12,16,22}$.

Thus, the results found in the present investigation suggest a new strategy for the physical education professional from resistance exercises, to work on the prevention of SUI considering this method as a way of establishing a coadjuvant approach for the treatment and prevention of urinary incontinence during practice of physical and sports exercises.

Since during the exercises no tests were performed to verify the level of contraction of the muscles involved in the proposed postures, it was not possible to identify which one presents a greater efficiency in the activation of the pelvic floor. Therefore, it is considered the continuity of this work, from future investigations that carried out electromyographic studies in the specific postures and in the corresponding bodybuilding exercises (in isometric contraction, seeking to identify the level of activation of the pelvic floor musculature) aiming at the improvement of the technique and, consequently, greater efficiency in the work and better results in the intervention.

\section{CONCLUSION}

The kinesiological study revealed that the muscles involved in the exercises postures for the prevention of UI, in addition to those specific to the pelvic floor, were: trunk flexors, spine erector, adductors and hip extensors. The corresponding physical exercises for these 
positions in bodybuilding machines were the hack machine, the stiff, the adductor chair, the abductor chair, the smith machine squat and the squat free or in the machine.

Therefore, it was possible to establish correspondence between the exercises for the MAP and resistance exercises with bodybuilding equipment and free weights. From the kinesiological study, it was possible to relate the muscular activation identified in the MAP and the activation that would also be required with the resistance exercises, allowing the construction of strategies to prevent UI during this practice.

All authors declare no potential conflict of interest related to this article

AUTHORS' CONTRIBUTIONS: Each author made significant individual contributions to this manuscript. ASC (0000-0001-5349-3222)*: conception of the research, drafting of the work. FSS (0000-0002-4745-5788)*: drafting of the methods, kinesiological analysis. MHBML (0000-0001-7747-1140)*: review of the article. All authors participated and approved the final version of the manuscript. *ORCID (Open Researcher and Contributor ID).

\section{REFERÊNCIAS}

1. Abrams P, Cardoso L, Fall M, Griffiths D, Rosier P, Ulmsten U, et al. The standardization of terminology of lower urinary tract function: report from the standardization sub-committee of The International Continence Society. Urology. 2003;61(1):37-49.

2. van Geelen JM, Hunskaar S. The epidemiology of female urinary incontinence. Eur Clin Obstet Gynaecol. 2005;1(1): 3-11.

3. Nygaard IE, Shaw JM. Physical activity and the pelvic floor. Am J Obstet Gynecol. 2016;214(2):164-71.

4. Eliasson K, Edner A, Mattsson E. Urinary incontinence in very young and mostly nulliparous women with a history of regular organised high-impact trampoline training: occurrence and risk factors. Int Urogynecol J Pelvic Floor Dysfunct. 2008;19(5):687-96.

5. Bø K. Urinary incontinence, pelvic floor dysfunction, exercise and sport. Sports Med. 2004;34(7)):451-64.

6. Bø K, Hagen R, Kvastein B, Larsen F. Female stress urinary incontinence and participation in different sport and social activities. Scand J Sports Sci. 1989;11(3):117-21.

7. Bø K, Borgen JS. Prevalence of stress and urge urinary incontinence in elite athletes and controls. Med Sci Sports Exerc. 2001;33(11):1797-802.

8. Nygaard IE, Thompson FL, Svengalis SL, Albright JP. Urinary incontinence in elite nulliparous athletes. Obstet Gynecol. 1994;84(2):183-87.

9. Nygaard IE, Glowacki C, Saltzman CL. Relationship between foot flexibility and urinary incontinence in nulliparous varsity athletes. Obstet Gynecol. 1996;87(6):1049-51.

10. Nygaard IE. Does prolonged high-impact activity contribute to later urinary incontinence? A retrospective cohort study of female Olympians. Obstet Gynecol. 1997;90(5):718-22.

11. Borin LC, Nunes FR, Guirro ECO. Assessment of pelvic floor muscle pressure in female athletes Phys Med Rehabilit. 2013;5(3):189-93.

12. Da RozaT, de Araujo MP, Viana R, Viana S, Jorge RN, Bø K, et al. Pelvic floor muscle training to improve urinary incontinence in young, nulliparous sport students: a pilot study. Int Urogynecol J. 2012;23(8):1069-73.

13. Bø K, Bratland-Sanda S, Sundgot-Borgen J. Urinary incontinence among group fitness instructors including yoga and pilates teachers. Neurourol Urodyn. 2011;30(3):370-3.

14. Eliasson K, Larsson T, Mattsson E. Prevalence of stress incontinence in nulliparous elite trampolinists. Scand J Med Sci Sports. 2002;12(2):106-10.

15. Da Roza T, Brandão S, Mascarenhas T, Jorge RN, Duarte JA. Volume of training and the ranking level are associated with the leakage of urine in young female trampolinists. Clin J Sport Med. 2015;25(3):270-5.

16. Fernandes AO, Fitz F, Silva A, Filoni E, Filho JM. Evaluation of the Prevalence of urinary incontinence symptoms in adolescent female soccer players and their impact on quality of life. Occup Environ Med. 2014;71(Suppl 1):A59-60.

17. Poswiata A, Socha T, Opara J. Prevalence of stress urinary incontinence in elite female endurance athletes. J Hum Kinet. 2014;44:91-6.

18. Caetano, AS, Tavares MC, Lopes MH. Incontinência urinária e a prática de atividades físicas. Rev Bras Med Esporte. 2007;13(4):270-4.

19. Vitton V, Baumstarck-Barrau K, Brardjanian S, Caballe I, Bouvier M, Grimaud JC. Impact of high-level sport practice on anal incontinence in a healthy young female population. J Womens Health (Larchmt) 2011;20(5):757-63

20. Greydanus DE, Omar H, Pratt HD. The adolescent female athlete: current concepts and conundrums Pediatr Clin North Am. 2010;57(3):697-718.

21. Caetano AS. Incontinence: Physical Activity as a Supporting Prevent Approach. In: Alhasso A, Fernando A. editors. Urinary Incontinence. Croatia: Intech; 2012. p. 69-88.

22. Lippert L. Cinesiologia Clínica e Anatomia. 5 ed. Rio de Janeiro: Guanabara; 2013.

23. Neumann DA. Cinesiologia do aparelho musculoesquelético: Fundamentos para a reabilitação física. 2 ed. Rio de Janeiro: Elsevier; 2011.

24. Caetano AS, Tavares MC, Lopes MHBM, Poloni RL. Influência da atividade fisica na qualidade de vida e auto-imagem de mulheres incontinentes Rev Bras Med Esporte. 2009; 15(2): 93-7.

25. Parmigiano TR, Zucchi EV, Araujo MP, Guindalini CS, Castro RA, Di Bella ZI. Avaliação ginecológica pré-participação da mulher atleta: uma nova proposta. Einstein (São Paulo). 2014;12(4):459-66.

26. Townsend MK, Danforth KN, Rosner B, Curhan GC, Resnick NM, Grodstein F. Physical activity and incident urinary incontinence in middle-aged women. J Urol. 2008;179(3):1012-6.

27. Bø K. Pelvic floor muscle training is effective in treatment of female stress urinary incontinence, but how does it work? Int Urogynecol J Pelvic Floor Dysfunct. 2004;15(2):74-84

28. Bø K. Mørkved S, Frawley H, Sherburn M. Evidence for benefit of transversus abdominis training alone or in combination with pelvic floor muscle training to treat female urinary incontinence: a systematic review. Neuroul Urodyn. 2009;28(5):368-73.

29. Sapsford RR, Richardson CA, Maher CF, Hodges PW. Pelvic floor muscle activity in diferente sitting postures in continente and incontinente women. Arch Phys Med Rehabil. 2008;89(9):174-7.

30. Totora DCB. O efeito do exercício resistido muscular globalizado em mulheres com incontinência urinária de esforço. [Dissertação de Mestrado]. Faculdade de Medicina da Universidade de São Paulo. São Paulo, 2010. 